\title{
Studi Eksplorasi Keberfungsian Full Day School Bagi Orangtua dan Anak pada SDIT Muhammadiyah 019 Bangkinang Kampar
}

\author{
Indah Puji Ratnani, Ricca Angreini Munthe \\ Fakultas Psikologi UIN Sultan Syarif Kasim Riau \\ indahpujiratnani@gmail.Com
}

\begin{abstract}
Full- day school was once an interesting topic in the community ,especially for parents. Full day school system offers a wide range of benefits for working parents, but still want the child to get maximum education. In fact, not all children feel the positive impact and comfort of a full day's system imposed. This research aims to determine the function of school full day for parents and children in SDIT Muhammadiyah 019 Bangkinang Kampar which has Tahfizcclass as the flagship program. The method of this research was qualitative descriptive which used data reduction, data presentation and conclusions. Data obtained from interviews, observations and documentation. Respondent in this study were one principal, three teachers, twenty parents and twenty-five Tahfiz-class Students. The results showed that both children and parentfelt the benefits of full day school. Children feel enjoy and happy. Parents feel the moral and academic achievement of the children are getting better after attending full day school.
\end{abstract}

\begin{abstract}
ABSTRAK
Sekolah full day menjadi sesuatu yang menarik perhatian masyarakat, terutama bagi orangtua. Sistem full day school menawarkan berbagai macam keuntungan bagi orangtua yang bekerja namun tetap menginginkan anak mendapatkan pendidikan maksimal. Kenyataanya, tidak semua anak merasakan dampak positif dan kenyamanan dari sistem full day yang diberlakukan tersebut. Penelitian ini bertujuan untuk mengetahui keberfungsian Full Day School Bagi Orangtua dan Anak Pada SDIT Muhammadiyah 019 Bangkinang Kampar yang memiliki kelas Tahfiz sebagai program unggulan. Penelitian ini adalah penelitian kualitatif deskriptif dengan reduksi data, penyajian data dan penarikan kesimpulan. Data diperoleh dari hasil wawancara, observasi dan dokumentasi. Responden dalam penelitian ini adalah satu orang kepala sekolah, tiga orang guru, dua puluh wali murid dan dua puluh lima siswa kelas tahfiz. Hasil penelitian menunjukkan bahwa anak dan orang tua sama-sama merasakan manfaat dari full day school. Anak merasakan perasaan senang dan bahagia. Orang tua merasakan perubahan akhlak dan prestasi akademik anak semakin baik setelah mengikuti full day school.
\end{abstract}

Keyword : Full day School, Orangtua, anak, SD IT

\section{Pendahuluan}

Lembaga pendidikan mempunyai peran yang sangat penting dalam pembinaan akhlak anak, terutama jika anak tidak mendapatkan tauladan atau contoh perilaku yang baik di rumah. Karena pada kenyataan saat ini kebanyakan anak Indonesia menghabiskan waktunya di sekolah. Oleh karena itu kebiasaan di sekolah akan menjadi salah satu cermin keperibadian anak ketika beranjak dewasa kelak.

Lembaga pendidikan saat ini banyak sekali yang memperdalam materi agama agar para peserta didiknya bisa menjadi generasi bangsa yang memiliki akhlak baik. Semua itu 
dilakukan untuk menjaga peserta didiknya dari kemerosotan moral dan degradasi akhlak bangsa. Menurut pendapat Sudarsono (1991: 7):

"Dewasa ini kenakalan remaja berkembang begitu luas sehingga banyak terjadi perbuatan-perbuatan asusila yang terjadi seperti masih banyak pencurian, pembunuhan, penggunaan narkoba, seks bebas dan perkelahian anak sekolah. Akibatnya perbuatan-perbuatan tersebut menimbulkan keresahan di dalam keluarga, sekolah dan masyarakat"

Mahmudi (2004: 62-63) menjelaskan faktor yang mendominasi kemerosotan akhlak, sebagaimana pendapatnya berikut ini:

"Faktor yang mendominasi terjadinya kemerosotan di atas adalah karena kurangnya pemahaman dan penghayatan terhadap akhlak, semakin hilangnya nilai-nilai agama dalam kehidupan dan semakin deras arus pergeseran atau dekadensi moral yang terjadi dikalangan masyarakat secara umum serta hilangnya loyalitas terhadap Islam"

Kasus seperti ini masih sering terjadi di Indonesia, dan hampir setiap hari berita-berita tentang kekerasan, pemerkosaan, selalu menghiasi layar televisi. Tergambar dengan jelas betapa merosotnya moral dan akhlak di negara ini. Padahal kualitas suatu bangsa sangat ditentukan oleh kualitas akhlaknya, jika akhlaknya sudah rusak maka hancurlah bangsa tersebut. Menurut Darajat (1989: 78) "salah satu timbulnya krisis akhlak yang terjadi dalam masyarakat adalah karena lemahnya pengawasan sehingga respon terhadap agama berkurang". Oleh sebab itu, peran orang tua dalam pendidikan agama untuk membina akhlak anak menjadi mutlak, karena melalui orang tua, anak memperoleh kesinambungan nilai-nilai kebaikkan yang telah diketahui di sekolah. Tanpa keterlibatan orang tua dan keluarga maka sebaik apapun nilai-nilai yang diajarkan di sekolah akan menjadi sia-sia, jika tidak diterapkan dalam kehidupan sehari-hari.

Pembinaan akhlak bagi setiap manusia adalah sebuah kewajiban yang harus dilakukan terus menerus tanpa henti baik melalui pembinaan orang lain maupun pembinaan diri sendiri serta pembiasaan dalam hal-hal yang dapat meningkatkan perbaikan akhlak seseorang. Menurut Khoiri (2005: 131) “Berbagai kerusakan dan kejahatan yang telah terjadi sampai saat ini akibat manusia tidak lagi memegang dan mengamalkan akhlak yang baik sehingga semakin merosot akhlaknya". Kurangnya perhatian masyarakat Islam sendiri terhadap pendidikan atau pembentukan akhlak merupakan hal yang mendorong terjadinya penurunan akhlak.

Guru sebagai individu yang berperan aktif dan kreatif sangat dituntut untuk dapat menunjang pembelajaran Pendidikan Agama Islam terutama pembentukan akhlak peserta didik, semua itu dapat dilakukan melalui keteladanan dan praktek nyata di lingkungannya. Tanggungjawab dalam menyiapkan generasi yang akan datang harus dipikirkan dan direncanakan secara matang oleh seorang guru dan orang tua agar terlahirlah generasi yang 
unggul dan berpendidikan. Karena membina akhlak merupakan bagian yang sangat penting dalam tujuan pendidikan nasional.

Berdasarkan Undang-Undang Sistem Pendidikan Nasional Nomor 20 Tahun 2003 pada bab II pasal 3, menyatakan bahwa:

"Pendidikan nasional berfungsi mengembangkan kemampuan dan membentuk watak serta peradaban bangsa yang bermartabat dalam rangka mencerdaskan kehidupan bangsa, bertujuan untuk berkembangnya potensi peserta didik agar menjadi manusia yang beriman dan bertakwa kepada Tuhan Yang Maha Esa, berakhlak mulia, sehat, berilmu, cakap, kreatif, mandiri, dan menjadi warga negara yang demokratis serta bertanggung jawab."

Berdasarkan Undang-Undang Sisdiknas di atas, sangat jelas bahwa tujuan dari pembinaan akhlak adalah untuk menjadikan peserta didik memiliki kepribadian yang baik dan dapat menjadi tauladan bagi semua orang. Moralitas merupakan faktor yang esensial. Maka dapat dibayangkan betapa rusaknya generasi bangsa manakala moralitas atau akhlaknya rapuh. Oleh karena itu, diperlukan upaya-upaya penanaman akhlak mulai sejak dini agar kelak anak dapat mengetahui mana perilaku yang baik dan perilaku yang buruk.

Pendidikan yang terjadi saat ini, banyak sekali lembaga pendidikan yang mengadakan sistem belajar sehari penuh bagi peserta didiknya atau yang sering dikenal dengan sebutan Full Day School. Program ini bertujuan untuk membina akhlak dan membentuk kepribadian yang baik pada peserta didiknya. Dalam sistem tersebut tidak hanya memberi pengetahuan saja akan tetapi juga disertai pembinaan akhlak agar peserta didik terbiasa melakukan perilaku-perilaku yang baik dan berakhlak dalam kehidupan sehari-hari.

Full Day School adalah salah satu sistem unggulan yang dirintis oleh beberapa sekolah yang ada di Indonesia. Sistem ini merupakan sebuah model pendidikan alternatif, dimana peserta didik sehari penuh berada di sekolah untuk melakukan proses pembelajaran dan proses beribadah. Tersedianya waktu yang cukup lama di lingkungan sekolah peserta didik perlahan-lahan akan terbiasa dengan kehidupan yang mandiri, dan menumbuhkan sikap kebersamaan dan kesadaran beribadah serta sikap positif lainnya yang dapat menjadikan peserta didik menjadi lebih baik. Sistem tersebut juga dapat digunakan untuk mengembangkan kreativitas dan bakat yang dimiliki peserta didik.

Full Day School berbeda dengan sekolah dasar pada umumnya yang hanya melakukan proses pembelajaran setengah hari yaitu mulai dari pukul 7:00 sampai 12:00. Selain itu peserta didik di sekolah dasar pada umumnya hanya belajar pengetahuan saja tanpa diimbangi dengan pembiasaan seperti shalat berjamaah, disiplin makan dan pembiasaan sopan santun. Sepulang sekolah mereka pun menghabiskan waktunya untuk bermain dengan teman-temannya di lingkungannya, sehingga pengawasan orang tua pun tidak maksimal dikarenakan banyak dari orang tua yang disibukan dengan pekerjaan. Pergaulan yang kurang pengawasan dari orang tua 
itulah dikhawatirkan peserta didik akan meniru perilaku-perilaku atau perbuatan yang tidak seharusnya mereka contoh.

Sa'adah (2012) sistem full day school pada saat ini memang dinilai cukup memberi alternative bagi beberapa pihak antara lain:

"Pertama, bagi kalangan orang tua khususnya bagi mereka yang sibuk dengan pekerjaan, sehingga akan memudahkan kontrol atas anak-anak mereka. Kedua, kekhawatiran akan pengaruh dari aspek lingkungan seperti pergaulan bebas, tawuran antar siswa, penggunaan obat-obat terlarang dll. Ketiga, dari pihak guru lebih bisa mengetahui proses pembelajaran pada siswa mereka (http://apikdw.wordpress.com)."

Sebagai sistem yang tergolong baru, full day school merupakan suatu sistem yang masih asing bagi beberapa sekolahan karena baru sedikit yang menggunakan program tersebut untuk meningkatkan kualitas pendidikan di sekolah masing- masing. Diantara sekolah yang menerapkan sistem full day school adalah Sekolah Dasar Islam Terpadu (SDIT) Muhammmadiyah 019 Bangkinang yang merupakan salah satu lembaga pendidikan dasar yang telah berhasil menerapkan system tersebut. Hal itu dapat dibuktikan dari prestasi yang telah diraih oleh SD Muhammmadiyah 009 Bangkinang baik di tingkat lokal maupun nasional. Keberadaan SDM 009 Bangkinang telah mendapatkan hati tersendiri bagi masyarakat Bangkinang khususnya dalam hal pembangunan karakter anak didik melalui program-program kegiatan yang mengarah pada pembentukan karakter anak yang islami.

Melalui sistem full day school yang diterapkan dapat mengkontrol peserta didik dalam bertingkah laku. Selain itu, juga ada pengawasan dan pantauan guru yang ada di sekolah, agar peserta didik dapat berkembang dengan baik, karena tidak hanya kegiatan keagamaan saja yang dapat memberi pendidikan akhlak pada peserta didik, tapi membiasakan sikap tolong menolong dengan sesama, tanggung jawab, disiplin dan perbuatan baik lainya. Semua itu agar terbentuknya akhlak yang baik pada diri peserta didik untuk bekal masa depan kelak.

Salah satu program unggulan SDIT Muhammadiyah 019 Bangkinang Kampar adalah program Tahfiz yang baru berjalan tiga tahun. Target mereka adalah satu juz setiap tahun sehingga nanti di kelas VI sudah mampu menghapal enam juz. Hal ini menjadi sangat menarik karena sebagaimana yang diketahui bahwa kegiatan full day school memiliki pro dan kontra. Salah satu kontradiksi yang sering bermunculan adalah anak merasa kelelahan dengan kegiatan full day school. Beberapa penelitian terdahulu juga menemukan bahwa full day school bagi anak Sekolah Dasar memiliki kerentanan terhadap stres karena terdapat banyak tuntutan terhadap mereka. Namun, masih banyak orangtua yang merasa bahwa full day school sangat membantu mereka dalam memberikan pendidikan pada anak

Berdasarkan latar belakang yang diuraikan di atas, maka peneliti ingin mengetahui siapa yang sebenarnya mendapat keuntungan ataupun manfaat dari sistem full day school, 
sehingga peneliti tertarik untuk melakukan penelitian dengan judul "Studi Eksplorasi Keberfungsian Full Day School Bagi orangtua dan anak pada SDIT Muhammadiyah 019 Bangkinang, Kampar".

\section{Metode Penelitian}

Pendekatan ini mencoba meneliti dan mempelajari sikap dan tingkah laku manusia sebagai gambaran dari gejala-gejala kejiwaan seseorang, karenanya penelitian ini menggunakan pendekatan kualitatif. Lokasi penelitian dilakukan di SDIT Muhammadiyah 019 Bangkinang, Kampar. Subyek penelitiannya adalah informan yang di anggap dapat memberikan informasi secara akurat. Adapun data yang diperoleh dari penelitian ini berasal dari: (1). Kepala sekolah dan wakasek SDIT Muhammadiyah 019 Bangkinang, Kampar yaitu orang yang mengatur dan mengontrol berjalannya proses pembelajaran dalam sistem full day school, (2) Guru dan wali kelas SDIT Muhammadiyah 019 Bangkinang, Kampar, yang berjumlah 3 (tiga) orang, (3).Wali murid SDIT Muhammadiyah 019 Bangkinang, Kampar yang mengikuti sistem full day school, dan () . Peserta didik yang duduk di kelas III Tahfiz. Untuk mendapatkan data dan informasi yang mendukung penelitian ini, maka langkah-langkah yang dilakukan untuk mengumpulkan data adalah: (1) Observasi, (2). Wawancara, dan (3) dokumentasi. Analisis data dilakukan dengan tiga langkah sebagai berikut:

a. Reduksi Data

Reduksi data merupakan kegiatan pemilihan, penyederhanaan dan transformasi data kasar yang muncul dari catatan tertulis di lapangan, sehingga menjadi lebih fokus sesuai dengan obyek penelitian. Reduksi data berlangsung selama proses penelitian sampai tersusunnya laporan akhir penelitian.

b. Penyajian Data

Penyajian data sekumpulan informasi yang memberikan kemungkinan adanya penarikan kesimpulan dan pengambilan tindakan. Penyajian data dalam skripsi ini merupakan penggambaran seluruh informasi tentang bagaimana sistem full day school dalam pembinaan akhlak peserta didik.

c. Penarikan kesimpulan

Penarikan kesimpulan merupakan suatu kegiatan konfigurasi yang utuh. Setelah analisis dilakukan, maka peneliti dapat menyimpulkan masalah yang ditetapkan oleh peneliti. Dari hasil pengolahan dan penganalisian data ini kemudian diberi interpretasi terhadap masalah yang akhirnya digunakan oleh peneliti sebagai dasar untuk menarik kesimpulan. 


\section{Hasil dan Pembahasan}

\section{A. Hasil Penelitian}

Peneliti melakukan wawancara terhadap dua orang guru SDIT 019 Muhammadiyah dan satu orang guru walikelas Tahfis (Kelas III) dan Wakil kepala sekolah beserta Kepala sekolah sebagai key person dalam penelitian ini. Selain itu, peneliti melakukan observasi dan wawancara kepada siswa kelas III Tahfis dan memberikan kuesioner pada orangtua. Dari 25 kuesioner yang diberikan yang kembali hanya 20 kuesioner. Dokumen hasil belajar siswa juga digunakan untuk melihat pola nilai siswa pada tiap semester.

\section{Manfaat Full Day School yang dirasakan oleh siswa \\ a. Perasaan Senang sebagai siswa}

Peneliti menemukan bahwa seluruh siswa merasa senang sekolah di SDIT Muhammadiyah 019 Bangkinang, hal tersebut diperoleh dari hasil wawancara terhadap 24 orang siswa dan observasi yang dilakukan oleh peneliti. Mereka menunjukkan antusiasme dalam mengikuti pelajaran yang ditandai dengan suara lantang dalam menjawab salam ketika kelas setelah istirahat siang dimulai, mereka tidak tampak lelah. Namun dari hasil wawancara tersebut terdapat 4 orang anak yang mengaku pernah merasa lelah dan tidak ingin datang ke sekolah. Hal tersebut hanya terjadi satu hingga dua kali selama mereka di kelas 3 SDIT Muhammadiyah 019 Bangkinang kota.

Siswa siswi merasa senang bersekolah di SDIT Muhammadiyah 019 Bangkinang karena mereka memiliki banyak teman di sekolah baik yang satu kelas dengan mereka maupun tidak. Selain itu, mereka juga mengemukakan bahwa mereka senang karena banyak kegiatan menghapal Al-Qur'an hal ini dapat dipahami dari hasil wawancara berikut:

"Senang, karena banyak teman dan menghapal Al-Qur'an" (SFDSF)

"Senang karena lebih banyak menghapal Al-Qur'an" (WJZSF)

Hal tersebut menunjukkan bahwa siswa memang tertarik untuk menghapal Al-Qur'an dan juga mereka mengungkapkan tidak pernah dimarahi ataupun dihukum ketika tidak hapal. Hal tersebut sesuai dengan pernyataan YS:

"Kalau tidak hapal ga apa-apa, paling cuma disuruh menghapal lagi di rumah oleh pak guru" (SKYS)

Sebagaian besar siswa sudah menghapal minimal 2 Juz dan ada yang sampai 7 Juz namun ratarata anak sudah menghapal 2,5 hingga 3 karena target sekolah setiap tahun mulai dari kelas 1 adalah 1 Juz sehingga ketika selesai kelas 3 mereka sudah hapal 3 Juz. Hasil wawancara tersebut dikemukakan oleh salah seorang guru (AM):

"mereka punya target setiap tahun menghapal 1 juz dan sejauh ini mencapai target" (GH27) 


\section{b. Kompetensi sikap}

Peneliti menggunakan laporan penilaian hasil belajar siswa yang diperoleh dari orangtua siswa untuk melihat kompetensi sikap siswa. Kompetensi sikap terdiri dari sikap spiritual dan sikap sosial. Sikap spiritual merupakan sikap taat beribadah, khusuk berdo'a sebelum dan sesudah kegiatan, tertib membaca Al-Qur'an dan mengucapkan salam. Sedangkan sikap sosial merupakan sikap jujur, disiplin, tanggung jawab, teliti dan percaya diri. Perkembangan kompetensi sikap siswa menunjukkan bahwa kompetensi sikap pada siswa SDIT Muhammadiyah 019 ketika mereka di kelas 1 dan 2 sangat baik. Hanya 3 orang yang mengalami penurunan kompetensi sikap pada kelas 2 semester 1 ( 1 orang pada aspek sosial dan 2 orang pada aspek spiritual)

Kondisi tersebut juga di jelaskan oleh guru kelas bahwa memang pada kelas II semester I siswa mengalami penurunan beberapa kemampuan baik sikap maupun pengetahuan karena hapalan sudah mulai banyak dan mereka masih butuh waktu penyesuaian

\section{c. Kompetensi Pengetahuan dan Keterampilan}

Kompetensi pengetahuan dan keterampilan dinilai pada setiap muatan pelajaran, yaitu Pendidikan Agama dan Budi Pekerti, Pendidikan Pancasila dan Kewarganegaraan, Bahasa Indonesia, Matematika, Seni Budaya dan Prakarya, Pendidikan Jasmani, Olah Raga dan Kesehatan, Muatan Lokal (Tahfiz). Data dari 12 siswa yang diperoleh oleh peneliti nilai paling tinggi yang diperoleh siswa adalah A dan paling rendah adalah B. nilai tersebut relative menetap dan tidak terlalu banyak berubah pada setiap semester. Hal ini menunjukkan bahwa tidak terdapat permasalahan yang berarti pada siswa SDIT Muhammadiyah 019 dalam hal akademis. Hal tersebut juga diperkuat oleh pernyataan walikelas mereka:

"hafalan juz ini menjadi penting dan berpengaruh pada pendidikan mata pelajaran umum, karena mereka cepat dalam menghafal juz maka anak juga cepat dalam mengingat, memahami dan menghafal setiap materi pelajaran umum" (GF31)

\section{Manfaat Full Day School yang dirasakan oleh orang tua}

Peneliti menyebarkan kuesioner kepada orangtua dengan beberapa pertanyaan untuk mengetahui keberfungsian Full Day School yang dilaksanakan oleh SDIT Muhammadiyah 019 sehingga diperoleh hasil sebagai berikut:

\section{a. Pendapat orangtua mengenai Full Day School}

Sebagian besar orang tua menyatakan bahwa program ini efektif dan mereka merasa terbantu dalam memberikan pembelajaran mengenai Al-Qur'an kepada anaknya, selain itu orang tua juga merasa bahwa program ini sangat baik dalam menunjang mutu pendidikan anak dan mendukung. Namun, ada juga orangtua yang merasa bahwa sistem Full Day School 
sebenarnya kurang tepat untuk anak usia dibawah kelas IV karena mereka masih membutuhkan waktu untuk bermain

\section{b. Program yang disukai}

Beberapa program yang diminati oleh orangtua adalah Program Tahfiz, Program Dokter Cilik, Outdoor dan Sholat berjamaah.

\section{c. Program yang tidak disukai}

Orang tua juga merasa ada beberapa program yang tidak mereka sukai yaitu Terlalu banyak Jam olahraga sehingga anak lelah dan program kerajinan tangan yang tidak sesuai dengan tingkatan sekolah anak sehingga yang mengerjakan adalah orang tua.

\section{d. Perubahan pada anak}

Beberapa perubahan yang terjadi pada siswa selama mereka menjadi siswa di SDIT Muhammadiyah 019 Bangkinang adalah:

1) Terjadinya peningkatan hafalan Al-qur'an anak: dapat membaca, sholat dan menghapal Surat (Al-Qur'an),

2) Peningkatan akhlak dan budi pekerti: anak menjadi dewasa, mandiri, disiplin, Akhlak anak lebih baik seperti lebih mampu menghargai orang tua, sholat lima waktu lebih tepat waktu, lebih banyak mengetahui sifat-sifat teladan nabi Muhammad S.A.W dan memiliki jiwa nasionalisme yang beragama.

3) peningkatan pada suasana emosi: anak menjadi lebih ceria dan semangat untuk sekolah

4) peningkatan pada akademik: nilai di sekolah semakin meningkat.

\section{e. Pendapat orang tua mengenai program Tahfiz}

Orang tua merasa bahwa Program Tahfiz sangat baik bagi anak terutama dalam hal mengenali surat-surat dan ayat-ayat Al-Qur'an dan membuat anak menjadi lebih cerdas dan akhlaknya juga baik. Program ini sangat bagus karena anak dapat menghapal Al-Qu'an dengan mudah meskipun perlu peningkatan terutama untuk anak yang lamban dalam menghapal.

\section{f. Saran orangtua terhadap SDIT Muhammadiyah 019 Bangkinang}

Hasil kuesioner yang dibagikan oleh peneliti menemukan beberapa saran orang tua terhadap SDIT Muhammadiyah 019 Bangkinang, yaitu: menambah jam belajar bahasa arab, jangan membeda-bedakan murid, pengumuman murid nilai tertinggi pada saat penerimaan laporan hasil belajar, kemudahan akses jalan menuju sekolah, pertahankan mutu dan kualitasnya, perbanyak pelajaran mengenai etika dan sopan santun kepada orangtua, ikuti kemajuan perkembangan pendidikan, tingkatkan murajaahnya, perlu kejelasan target, perbanyak kegiatan di luar sekolah, penambahan guru Tahfiz, ciptakan suasana yang lebih 
menyenangkan, meniadakan Tugas Rumah, perluasan parkir, perhatikan cuaca, jika memang akan hujan sebaiknya anak segera dipulangkan.

Prestasi belajar menurut Syah (2004: 154-156) terletak pada tiga ranah, yaitu:

a. Prestasi yang bersifat kognitif, seperti kemampuan siswa dalam mengingat, memahami, menerapkan, mengamati, menganalisa, membuat analisa dan lain sebagainya. Konkritnya, siswa dapat menyebutkan dan menguraikan pelajaran minggu lalu, berarti siswa tersebut sudah dapat dianggap memiliki prestasi yang bersifat kognitif.

b. Prestasi yang bersifat afektif, siswa dapat dianggap memiliki prestasi yang bersifat afektif, jika ia sudah bisa bersikap untuk menghargai, serta dapat menerima dan menolak terhadap suatu pernyataan dan permasalahan yang sedang mereka hadapi.

c. Prestasi yang bersifat psikomotorik, yang termasuk prestasi yang bersifat psikomotorik yaitu kecakapan eksperimen verbal dan nonverbal, keterampilan bertindak dan gerak. Misalnya seorang siswa menerima pelajaran tentang adab sopan santun kepada orang lain, khususnya kepada orang tuanya, maka si anak sudah dianggap mampu mengaplikasikannya dalam kehidupannya.

\section{Pembahasan}

Penerapan sistem full day school yang dilakukan oleh SDIT Muhammadiah 019 Bangkinang Kampar terutama dalam kelas kuhusus Tahfiz memberikan dampak positif baik bagi siswa ataupun orangtua. Orangtua sangat merasa terbantu dalam mendidik anak dan mengubah perilaku anak kearah yang lebih positif. Hal tersebut sesuai dengan pendapat Baharuddin (2010) yang menyatakan bahwa salah satu keunggulan sistem full day school adalah anak mendapatkan pendidikan kepribadian yang bersifat antisipatif terhadap perkembangan sosial budaya yang ditandai dengan derasnya arus informasi dan globalisasi.

Baharudin (2010: 225) menyatakan bahwa "konsep pengembangan dan inovasi pembelajaran sistem full day school didesain untuk mengembangkan kreativitas anak mencakup aspek kognitif, afektif danpsikomotor". Full day school memiliki keunggulan dan beberapa nilai plus diantaranya:

a. Anak memperoleh pendidikan umum antisipasi terhadap perkembangan ilmu pengetahuan;

b. Anak mendapatkan pendidikan kepribadian yang bersifat antisipatif terhadap perkembangan sosial budaya yang ditandai dengan derasnya arus informasi dan globalisasi;

c. Potensi anak tersalurkan melalui kegiatan ekstrakurikuler yang diadakan sekolah; 
d. Perkembangan bakat, minat, dan kecerdasan terantisipasi sejak dini melalui pantauan program bimbingan dan konseling.

Titik tekan pada full day school adalah siswa selalu berprestasi belajar dalam proses pembelajaran yang berkualitas yakni diharapkan akan terjadi perubahan positif dari setiap individu siswa sebagai hasil dari proses dan aktivitas dalam belajar.

Proses inti sistem pembelajaran full day school adalah proses pembelajaran yang berlangsung secara aktif, kreatif, transformatif sekaligus intensif. Sistem persekolahan dengan pola full day school mengindikasikan proses pembelajaran yang aktif dalam artian mengoptimalisasikan seluruh potensi untuk mencapai tujuan pembelajaran secara optimal baik dalam pemanfaatan sarana dan prasarana di lembaga dan mewujudkan proses pembelajaran yang kondusif demi pengembangan potensi siswa yang seimbang. Kemudian, proses pembelajaran yang dilakukan selama aktif sehari penuh tidak memforsir siswa pada pengkajian, penelaahan yang terlalu menjenuhkan. Hal tersebut yang membuat anak merasa senag dan bersemangat meskipun berada disekolah seharian penuh. Meskipun demikian, aspek kepribadian, pengetahuan dan keterampilan juga dapat mereka capai.

\section{Simpulan}

Keberfungsian sistem full day school di SDIT Muhammadiah 019 Bangkinang Kampar dirasakan baik oleh orangtua dan siswa. Mereka menunjukkan sikap positif dan mendukung sistem full day tersebut meskipun mereka juga memberikan beberapa masukan terkait dengan kegiatan yang menurut mereka terlalu banyak menggunakan aktifitas fisik. Siswa merasa senang dan menyukai sistem full day school yang mereka jalani dan orangtua merasakan perubahan perilaku anak kearah yang lebih positif terutama dalam menunjukkan perilaku menghargai orang yang lebih tua. Selain itu, program ini menunjukkan dampak yang positif pada aspek kompetensi sikap, pengetahuan dan keterampilan meskipun menambah muatan kurikulum untuk menghapal Al-Qur'an.

\section{Saran}

Studi perbandingan kelas tahfiz dan non tahfiz perlu dilakukan untuk melihat mana yang lebih efektif. Selain itu, pihak sekolah juga perlu memperhatikan saran dari orangtua terkait perlakuan, metode mengajar dan fasilitas sekolah.

\section{Daftar Pustaka}

Arikunto, Suharsimi. 1993. MeneJemen Penelitian, cet kedua. Jakarta: Rineka CIpta.

Baharuddin. 2010. Pendidikan dan Psikologi perkembangan. Jogjakarta: Ar-Ruzz Media. 
Darajat, Zakkiah. 1989. Peranan Agama Dalam Kesehatan Mental. Jakarta: Gunung Agung.

Khoiri, Alwan dkk. 2005. Akhlak Tasawuf. Yogyakarta: Pokja Akademik.

Mahmudi. 2005. Manajemen Kinerja sektor publik. Yogyakarta: UPP AMP.

Moleong, Lexy J. 2007. Metodologi Penelitian Kualitatif. Bandung: Remaja Rosdakarya

Sa'adah, Laila. "Pembelajaran Interaksi Sosial dalam Full Day School" dalam http://apikdw.wordpress.com, diakses pada tanggal 27 Januari 2016, jam 21:00 WIB

Sudarsono. 1991. Etika Islam Tentang Kenakalan Remaja. Jakarta: Rineka Cipta.

Sugiyono. 2008. Metode Penelitian Kualitatif, Kualitatif Dan $R$ dan D. Bandung: Alfabeta

Sukardi. 2009. Metodologi Penelitian Pendidikan, Kompetensi dan Praktiknya. Yogyakarta: PT. Bumi Aksara.

Sukmadinata, Nana Syaodih. 2010. Metode Penelitian Pendidikan. Bandung: PT. Remaja Rosda Karya.

Syah, Muhibbin. 2004. Psikologi Pendidikan dengan Pendekatan Terpadu. Bandung: Remaja Rosdakarya.

Undang-Undang Republik Indonesia Nomor 20 Tahun 2003 Tentang Sistem Pendidikan Nasional mulai berlaku tanggal 8 Juli 2003 